\title{
Analyzing the Barriers and Possibilities with $p$-values towards Starting a New Postgraduate Computer and Engineering Programs at Najran University: A Cross-Sectional Study
}

\author{
Abdullah Alghamdi \\ Department of Information Systems \\ Najran University \\ Najran, The Kingdom of Saudi Arabia
}

\begin{abstract}
A cross-sectional study was conducted to find out the barriers and their possible solutions to start a new postgraduate computer and engineering programs at Najran University (NU), Kingdom of Saudi Arabia. This study includes interviews and surveys consist of 35 questions. The total number of the participant was 363 ; most of them were employees at the government and private sectors. In this study to analysis the result IBM's Statistical Package for the Social Sciences (SPSS) version 22 is used to analyze the result with the respective $p$-values calculated using the Pearson Chi-square test. Study reveals that $95.6 \%$ of participants want to pursue a graduate degree. However, only $(\mathbf{4 6 . 9 \% )}$ ) can communicate in English academically. Among the respondents, about $(42.1 \%)$ started a graduate program before, but only $(11 \%)$ has completed the program. Others could not continue their graduate programs because they were not able to attend the classes coming from a far distance and uncomfortable classes schedule and time. Hence, questions were distributed among the participants to get their opinions to find the solution. Study reveals that among the participants' both government and private sectors employees shown the importance to have online classes with $(69.56 \%)$ and to have a comfortable schedule and time of courses with (95.65\%). This study outlined the main barriers and possible solutions and recommendations that may be helpful for higher education institutions and organizations to start new graduate programs.
\end{abstract}

Keywords-Postgraduate program; p-values; barriers; Najran university; English language; schedule

\section{INTRODUCTION}

Starting a new graduate program in computer science and engineering is a complicated process and it requires a lot of strategic planning, curriculum building, and dedication of resources. This process gets even more complicated when starting the new program in a public, and government funded university. While going through this process, the author concluded that it is very important to document and share this experience.

As a newly appointed head of information systems department, and with average and minimum expertise in academia and management respectively, the author realized the need to have a postgraduate program in the department.
This program would be the first in computer science and engineering colleges of Najran University (NU), a 12 years old and far southern rural government funded university in Saudi Arabia. The computer science and engineering colleges are the twin colleges of the university starting with one dean for both colleges, a mathematician who grounded the same rules and set the directions for both colleges. In addition, both colleges have the same number of departments and about the same number of students and graduates every semester. Opening a new postgraduate program would be the first step toward a new vision for the computing and engineering majors in NU which in result would shift the focus to research rather than being on education only.

The author in this paper documented the experience in opening a new postgraduate major. The organization of this paper as follow: Section II: the author offers a literature review on computer education in general, and Section III: the author states the methodology followed in this research. After that, the results are presented in Section IV. Then, challenges and recommendations are presented in Section V, while the conclusion is stated in Section VI.

\section{RELATED WORK}

Developing and managing graduate programs is a complex process. In 2000, Eriksson has the chance to develop the guidelines for the doctoral programs in Malardens Hogskola University, a small university in Sweden [3]. Their focus was on how to develop a graduate education that maintains quality standards of Swedish education, while taking the findings of subcommittee of the association of universities in Sweden (SUHF) postgraduate study [3] into account. They invited all departments to propose postgraduate programs. In their first round, two proposal were rejected due to the clarity of the proposal, shape of the department made that proposal, and insufficient resources. The study also analyze the process of designing: syllabus, joint courses, individual study plans, supervisor selections, thesis defense mechanism. On the other hand, Cullen et al. studies the ways of promoting effectiveness in Ph.D. supervision in Australian universities [4]. The authors recommend that the students should have access to 
supervision panel rather than one supervisor which in result would provide the students with broader range of skills and expertise. Among other recommendations, the authors emphasized that students should be concentrated in groups of sufficient numbers, professor professional development should be provisioned, and a period of structured induction should be introduced.

The facilitators and barriers to attaining a postgraduate degree in South Africa are discussed in [5] where, lack of financial support, family commitments and lack of time are found the mentionable barriers among the postgraduate students. Whereas, students who had obtained a postgraduate degree thought one can facilitate through the degree by gaining of expertise, the fulfilment of a personal goal (personal development) and improvement of patient care (career perspective) as participants. Students with lack of motivation found one of the major barriers for not obtaining a postgraduate degree. The rate was significantly more likely $(p<0.05)$ to report [5]. Not enough funding [6], inflexibility of available programs [7], family commitments and geographical location [8], lack of time, personal motivation and recognition in terms of increased pay or promotion [9] are major causes and additional barriers to not pursuing or not completing postgraduate studies. Authors in [10] mentioned that a lack of training on academic writing and low publication rate in undergraduate programs poses a barrier to not starting postgraduate physiotherapy program. Almost a similar problem found in Kuwait-based physiotherapists reporting publications in the academic journal [11].

Some research uncovers several themes in the students' motivations for doing a postgraduate degree include career development motives, academic motives, social environment self-formation motives, knowledge and awareness, academic considerations, financial cost and the influence of peer norms [12]. Other obstacles implicating in not conducting higher studies and research include inadequate resources and facility for research, lack of concentration by faculty or guide, and unavailability of required data or samples [13]. Other key challenges are cultural barriers and language proficiency issues mentioned in [14] as the major obstacles to pursuing graduate studies. Researchers in [15] suggest that blended learning, a relatively new concept in Saudi Arabia, shows promising results with higher student satisfaction. Blended learning is an active and passive student-centered learning that may enhance critical thinking and application. Learning experiences can be enriched by adopting a blended method of instruction at various stages of undergraduate and postgraduate education. Postgraduate students need to conduct more research to prepare them to venture into business as an entrepreneur [16]. Authors in [17] identified specific features of postgraduate medical education innovation that include designing the curriculum with the needs of the users in mind, the challenge of implementing other competencies than that of the medical expert; organize educational support. They also emphasize on the importance of regional and inter-organizational implementation strategies, curriculum, training and educational support; facilitate knowledge sharing; buildup inter-organizational networks and cooperation [17].

A thorough investigation is done by Symons to study the transition to higher degrees and the difficulties faced by the students who are beginning coursework postgraduate programs [18]. The difficulties include the worry about expectations, time spent away from school in the workforce and encountered issues when coming back to school. Also, the higher standards and studying a discipline that is different from their undergraduate. The author recommends a good induction and training programs to help students have a satisfactory start, which is similar to what Boyle and Boice [19], and Youngman [20] have concluded. Interestingly, MacKay[21], Golde[22], Jurgs et al. [23] are all agrees that there is a fundamental assumption among many schools that only the imperfect and unpleasant students are experiencing problems. This assumption leads to the conclusion that the student selection process in accepting students into a graduate school is the solution for all the issues that face the students who are beginning a graduate program. However, those studies [21-23] shows that assumption is inaccurate.

Padro et al. provide a comprehensive overview of academic leadership, doctoral education, and studentsupervisor relationship [24]. Also, the authors examine the external pressures including neoliberalism, accepting more students, quality benchmarking that faces the universities nowadays with focus on how to administer and deliver postgraduate programs. Besides, the authors provide recommendations to meet the organizational and students in many areas including professional, employment, information literacy, and processes of examinations.

The above information presents a paradox of sorts. Postgraduate studies appear to be the most efficient means of achieving growth in the profession-specific evidence. However, based on several reported barriers, globally there is a reluctance to pursue postgraduate studies. This study aims to investigate the potential limitation and provide recommendations to pursue postgraduate studies in Saudi universities, particularly in Najran University. It is hoped that the results of this study may be of benefit to policymakers and stakeholders in Najran University and other higher education providers to provide postgraduate studies for the students locally, regionally and globally.

\section{Methodology}

The methodology followed in this paper includes interviews, a survey distributed to a sample of interested parties, and investigations of rules and regulations of the university and education laws in the Saudi government. The questionnaire includes about 35 questions that cover the general information of the respondents, their education, and their relative education status. Also, it includes questions about the bachelor's degree majors, grades, willingness to start a postgraduate program, and preferred majors. According to the latest official population count, Najran region has about 570,000 people, while Najran city has 340,000 people [1]. The target of this study is the people who majored or has the possibility to major in computing and engineering fields. There is no exact number of the 
population size of this study, however, with educated predication, the author estimates the population size to be between 30000 - 50000 people. The prediction is based on the number of students entering computer science and engineering majors in last ten years, the number of students in high schools in Najran region, and estimated number IT and engineering professionals in government and private sectors organizations. The valid responses received from respondents are 363 responses. The confidence level is $95 \%$ with a margin of error of $5 \%$. In this study, the interviews conducted with current undergraduate students, faculty members, and officials from the city.

\section{MAJOR FInDINGS AND RESUlts ANALYSIS}

Table I presents the demographic characteristics of the participants. Most of the respondents in this study are males (91.7\%), while the females are about (8.3\%). The reason for this is that among all the departments in college of computer science and college of engineering, there is only two departments are available for female students, one of them started at Fall 2019. Many women lack the interest of participation in the study because they have not majored in majors of interest in this study. The majority of the respondents are between the age of 18 and 40 years old with about (84.3\%). When asked about the latest degree the participant achieved, only (11\%) has achieved a graduate degree including higher diploma, masters, or PhDs.

Table II evaluates participants' interest in pursuing a graduate program at Najran University (NU). When the participants are asked about the city they live in currently, about (95\%) live in Najran city and Najran region, which has an area of $365 \mathrm{Km}^{2}$ [2]. Aseer and Jazan regions are respectively $300 \mathrm{Km}, 650 \mathrm{~km}$ away from the capital of Najran region, Najran city. This question is included in this section to emphasize that there is no graduate program in IT and engineering in this whole region, and the nearest programs would be in King Khaled University (KKU), which is about $300 \mathrm{~km}$ away. Some of the participants in this study are majored in art, science, administrate and religion majors; however, the majority $(60 \%)$ are from IT and engineering majors. (95\%) of the participants are expecting to pursue their graduate degrees. Because the native language in Najran is Arabic and instruction in IT and engineering fields is in English, the participants were asked about their ability to communicate in English. Only (46.9\%) are able to academically communicate in English. An interesting result is that about (70\%) of the participants has started a graduate program sometime in the past. In Table I, the participants who finished their graduate degree are only (11\%). One reason for that is that there are many people who start their program; however, they drop out before they finish. One interviewee said he dropped out because it's was hard for him to travel every week to Aseer region to attend classes, while some others dropped because they could not study and work at the same time. Very significant number are expecting to pursue their graduate degrees, which is an interesting news for NU.
TABLE I. DEMOGRAPHIC CHARACTERISTICS OF PARTICIPANTS IN THE STUDY

\begin{tabular}{|l|l|}
\hline Variable & n (\%) \\
\hline Gender & $333(91.7)$ \\
\hline Male & $30(8)$ \\
\hline Female & \multicolumn{2}{|l|}{} \\
\hline Age & $3(0.8)$ \\
\hline less than 18 & $80(22)$ \\
\hline $18-24$ & $86(23.7)$ \\
\hline $25-30$ & $140(38.6)$ \\
\hline $31-40$ & $54(14.9)$ \\
\hline Above 40 & \\
\hline Nationality & $354(97.5)$ \\
\hline Saudi Citizen & $9(2.5)$ \\
\hline Non-Saudi & \\
\hline Occupation & $178(49)$ \\
\hline Government & $75(20)$ \\
\hline Private sector & $69(19)$ \\
\hline Students & $36(10)$ \\
\hline Unemployed & $5(2)$ \\
\hline Retired & $66(18.1)$ \\
\hline Latest Degree & $51(14)$ \\
\hline High school & $206(56.8)$ \\
\hline Associate degree & $40(11)$ \\
\hline Bachelor & $125(34.4)$ \\
\hline Graduate Degree & \multicolumn{2}{|l|}{} \\
\hline Has a relative with graduate degree & \\
\hline Yes & \\
\hline No & \\
\hline
\end{tabular}

TABLE II. EVAlUation of Participants' INTEREST TO PURSUING A GRADUATE PROGRAM AT NU

\begin{tabular}{|l|l|}
\hline Variable & $\mathbf{n}(\%)$ \\
\hline City & $118(32.5)$ \\
\hline Najran City & $226(62.2)$ \\
\hline Najran Region & $5(1.5)$ \\
\hline Aseer Region & $3(0.8)$ \\
\hline Jazan Region & $11(3)$ \\
\hline Others & \multicolumn{2}{|l|}{} \\
\hline Major & $153(42.1)$ \\
\hline IT & $65(17.9)$ \\
\hline Engineering & $49(13.5)$ \\
\hline Art and Science & $92(25.3)$ \\
\hline Administrative & $4(1.1)$ \\
\hline Religion & \\
\hline Participant has last degree from &
\end{tabular}




\begin{tabular}{|l|l|}
\hline NU & $77(21.2)$ \\
\hline King Khaled University KKU & $27(7.4)$ \\
\hline Jazan University JU & $3(0.8)$ \\
\hline Others & $182(50.1)$ \\
\hline Not Applicable & $74(20.4)$ \\
\hline Have you started a graduate program in the past \\
\hline Yes & $153(42.1)$ \\
\hline No & $210(57.9)$ \\
\hline Do you expect to pursue a graduate degree \\
\hline Yes & $347(95.6)$ \\
\hline No & $16(4.4)$ \\
\hline Ability to communicate in English \\
\hline Excellent & $67(18.5)$ \\
\hline Very good & $103(28.4)$ \\
\hline Good & $137(37.7)$ \\
\hline Poor & $51(14)$ \\
\hline Very Poor & $5(1.4)$ \\
\hline
\end{tabular}

Table III presents the participants motivation to pursue a graduate degree, the expected impact of earning a graduate degree on their careers, and the university they are interested in pursuing their careers on. More than (88\%) of the participants are agreeing that that the main motive for them to pursue their career is that because they are passionate about their field of study and they want to learn more. The majority of participants strongly agree that the graduate certificate would improve their career and would increase their chances of getting a new job with (60\%) and (58.4\%), respectively. When the participants were asked that improving the social status is a primary motive for them to pursue a graduate degree, (48\%) strongly agreed and (32\%) agreed, while only (9\%) did not agree. About (94\%) agreed that earning a graduate degree would help them get promotion at their jobs with only (1\%) who disagreed. In addition, (62\%) agreed that getting a graduate degree would help them changing their current career path. When the participants were asked what do they prefer: a public or private university to pursue their graduate degree at, (98\%) were interested in public university, while (27\%) were interested in pursuing a graduate degree in private university. When asked about which university they want to pursue their graduate degree at, about (92\%) preferred Najran University and that is due to the fact that the majority of the participants (95\%) are from Najran region.

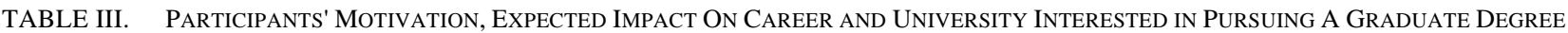

\begin{tabular}{|c|c|c|c|c|c|}
\hline Item & Strongly Agree & Agree & Neutral & Disagree & Strongly Disagree \\
\hline \multicolumn{6}{|c|}{ The motivation for pursuing a graduate degree } \\
\hline Passionate about the field of study & $177(48.8 \%)$ & $147(40 \%)$ & $29(8.7 \%)$ & $9(2.5 \%)$ & $0(0 \%)$ \\
\hline Improving my career & $216(60 \%)$ & $124(34 \%)$ & $15(4 \%)$ & $8(2 \%)$ & $0(0 \%)$ \\
\hline Increasing my chances in getting a new job & $212(58.4 \%)$ & $102(28.1 \%)$ & $29(8 \%)$ & $15(4.1 \%)$ & $5(1.4 \%)$ \\
\hline Improving my social status & $176(48 \%)$ & $116(32 \%)$ & $39(11 \%)$ & $24(7 \%)$ & $8(2 \%)$ \\
\hline \multicolumn{6}{|c|}{ The expected impact of earning a graduate degree } \\
\hline Promotion in my job & $244(67 \%)$ & $98(27 \%)$ & $17(5 \%)$ & $3(1 \%)$ & $0(0 \%)$ \\
\hline $\begin{array}{l}\text { Increasing my chances to get a job at better } \\
\text { place }\end{array}$ & $209(58 \%)$ & $106(29 \%)$ & $35(9.6 \%)$ & $11(3 \%)$ & $2(0.4 \%)$ \\
\hline Changing my current career path & $135(37 \%)$ & $89(25 \%)$ & $54(15 \%)$ & $71(19 \%)$ & $14(4 \%)$ \\
\hline \multicolumn{6}{|l|}{ Want to pursue your graduate degree in } \\
\hline Public university & $331(91 \%)$ & $25(7 \%)$ & $3(1 \%)$ & $2(0.5 \%)$ & $2(0.5 \%)$ \\
\hline Private University & $46(13 \%)$ & $52(14 \%)$ & $92(25 \%)$ & $118(33 \%)$ & $55(15 \%)$ \\
\hline \multicolumn{6}{|c|}{ Very interested in pursuing my graduate degree in } \\
\hline Najran University NU & $286(79 \%)$ & $48(13 \%)$ & $13(3 \%)$ & $10(3 \%)$ & $6(2 \%)$ \\
\hline King Khaled University KKU & $56(15 \%)$ & $101(28 \%)$ & $82(23 \%)$ & $80(22 \%)$ & $44(12 \%)$ \\
\hline Jazan University JU & $51(14 \%)$ & $86(24 \%)$ & $87(24 \%)$ & $92(25 \%)$ & $47(13 \%)$ \\
\hline Others & $111(30.5 \%)$ & $54(14.8 \%)$ & $71(19.5 \%)$ & $89(24.5 \%)$ & $39(10.7 \%)$ \\
\hline
\end{tabular}


Table IV presents the majors that the participants would like NU to open a graduate program at. The participants were given a five-point scale to rate their interests in each program. Fourteen majors were presented to the participants, nine of which are IT majors, and 5 are engineering majors. Cybersecurity is the major that got the highest extremely interest with (66.1\%) followed by AI and Big Data major with (56.2\%). The networks and internet of things (IoT) major came third with (52\%). Actually, these three majors are very popular and trendy topics. Also, it is noticeable that the computer science majors are more favored among the participants by getting at least (74.1\%) of extremely and very interested votes in every major with exception of game design and development, while engineering majors are getting at their best chance (65.8\%) with electrical engineering major. Architectural, civil, chemical and electrical engineering majors have the highest votes on not interested at all option with $(5.8 \%, 5.2 \%, 4.7 \%, 4.7 \%)$, respectively.
We have already seen from Table II that a significant number of participants want to pursue their graduate degree (95.6\%). However, they are lack in their ability to communicate in English where the mode of instruction in IT and engineering field is in English. Only (46.9\%) can communicate in English academically. In this study, participants were asked whether they need English as an admission requirement to graduate programs. About (40.30\%) participants among an excellent English speaker, about (32\%) who are very good at English replied positively. While only (20\%) whose English communicative skills are very poor answered positively. The percentage of participants who are already good in English responded positively than that of participants who are weak in English. Overall success score to encompass the English language as graduate program entry requirements using the Chi-square test is considerable with p-value $<.05$ as presented in Table V. To analyze the result IBM's Statistical Package for the Social Sciences (SPSS) version 22 was used.

TABLE IV. COMPUTER SCIENCE AND ENGINEERING GRAdUATE MAJORS THAT PARTICIPANTS WOULD LIKE TO SEE AT NU

\begin{tabular}{|c|c|c|c|c|c|}
\hline Item & Extremely interested & Very Interested & $\begin{array}{l}\text { Moderately } \\
\text { interested }\end{array}$ & Slightly interested & $\begin{array}{l}\text { Not interested at } \\
\text { all }\end{array}$ \\
\hline Computer science & 173(47.7) & 101(27.8) & $44(12.1)$ & $35(9.6)$ & $10(2.8)$ \\
\hline Information Systems & 173(47.7) & $99(27.3)$ & 49(13.4) & $32(8.8)$ & $10(2.8)$ \\
\hline Software Engineering & $182(50.2)$ & $94(25.9)$ & $48(13.2)$ & $29(7.9)$ & $10(2.8)$ \\
\hline Cybersecurity & $240(66.1)$ & $66(18.2)$ & $33(9)$ & $21(5.8)$ & $3(0.9)$ \\
\hline AI \& Big Data & $204(56.2)$ & 83(22.9) & $43(11.8)$ & $28(7.7)$ & $5(1.4)$ \\
\hline Networks and IoT & $189(52)$ & $106(29.2)$ & $36(9.9)$ & $24(6.7)$ & $8(2.2)$ \\
\hline Human Computer Interaction & $155(42.7)$ & 114(31.4) & $52(14.3)$ & $34(9.4)$ & $8(2.2)$ \\
\hline Computer engineering & $182(50.2)$ & 101(27.8) & $44(12.1)$ & $32(8.8)$ & $4(1.1)$ \\
\hline Game Design and development & $150(41.3)$ & $80(22.1)$ & $75(20.6)$ & $48(13.2)$ & $10(2.8)$ \\
\hline Electrical Engineering & 157(43.3) & $82(22.5)$ & $64(17.7)$ & 43(11.8) & $17(4.7)$ \\
\hline Mechanical Engineering & $148(40.6)$ & $79(21.6)$ & 75(20.6) & $46(12.6)$ & $15(4.6)$ \\
\hline Chemical Engineering & 142(39.1) & $78(21.5)$ & 71(19.7) & $55(15)$ & $17(4.7)$ \\
\hline Civil Engineering & $150(41.3)$ & $79(21.6)$ & $70(19.4)$ & $45(12.5)$ & $19(5.2)$ \\
\hline Architectural engineering & 141(38.8) & $85(23.4)$ & 76(20.9) & $40(11.1)$ & $21(5.8)$ \\
\hline
\end{tabular}

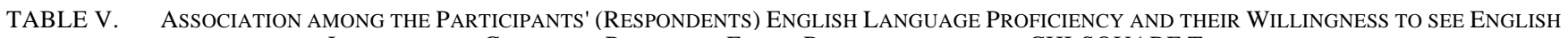
LANGUAGE As GRAdUATE Programs ENTRY REQUIREMENT USING CHI-SQUARE TEST

\begin{tabular}{|l|l|l|l|l|}
\hline \multirow{2}{*}{$\begin{array}{l}\text { Ability to communicate in } \\
\text { English }\end{array}$} & \begin{tabular}{l} 
Participants' opinions and observations over the English Language as the graduate programs entry requirement \\
\cline { 2 - 4 }
\end{tabular} & $\begin{array}{l}\text { No } \\
\mathbf{n}(\%)\end{array}$ & $\begin{array}{l}\text { Maybe } \\
\text { n (\%) }\end{array}$ & P-values \\
\hline Excellent & $27(40.30 \%)$ & $16(23.88 \%)$ & $24(35.82 \%)$ & $\begin{array}{l}X^{2}(5, N=363)=38.97, \\
P<0.00001\end{array}$ \\
\hline Very good & $33(32.04 \%)$ & $40(38.83 \%)$ & $40(29.13 \%)$ \\
\hline Good & $23(16.79 \%)$ & $73(53.28 \%)$ & $10(19.61 \%)$ \\
\hline Poor & $4(7.84 \%)$ & $37(72.55 \%)$ & $1(20 \%)$ & \\
\hline Very Poor & $1(20 \%)$ & $3(60 \%)$ & & \\
\hline
\end{tabular}


TABLE VI. RELATIONSHIP BETWEEN PARTICIPANTS' OCCUPATION (EMPLOYMENT) AND THEIR PREVIOUS ENROLMENT TO GRADUATE PROGRAMS USING CHI-SQUARE TEST

\begin{tabular}{|c|c|c|c|}
\hline \multirow{2}{*}{ Occupation } & \multicolumn{3}{|c|}{ Prior enrolment to graduate programs } \\
\hline & $\begin{array}{l}\text { Yes } \\
\text { n (\%) }\end{array}$ & $\begin{array}{l}\text { No } \\
\text { n (\%) }\end{array}$ & $P$ value \\
\hline Government & $64(35.96 \%)$ & $114(64.04 \%)$ & \multirow{5}{*}{$\begin{array}{l}\mathrm{X}^{2}(5, N=363)=24.60, \\
P=0.00006\end{array}$} \\
\hline Private sector & $31(41.33 \%)$ & $44(59.67 \%)$ & \\
\hline Students & $5(7.24 \%)$ & $64(92.76 \%)$ & \\
\hline Unemployed & $10(27.78 \%)$ & $26(72.22 \%)$ & \\
\hline Retired & $1(20 \%)$ & $4(80 \%)$ & \\
\hline
\end{tabular}

Among the participants, about (42.1\%) started a graduate program before, according to the data presented in Table II. All the participants in our study belong to a set of occupation having elements include government service holders, private sector, students, unemployment, and retired. According to the research and data revealed from Table VI, it is significant that both government and private sectors employees enrolled in graduate programs previously with (35.96\%) and (41.33\%) respectively. The overall score is considerable using the Pearson Chi-square test with p-value $<.05$, as presented in Table VI.
In our study, when asked about the latest degree the participants achieved, only (11\%) has completed a graduate degree, including higher diploma, masters, or $\mathrm{PhDs}$ according to data presented in Table I. One reason for that is many people start their program; however, they drop out before they finish. One interviewee said he dropped out because it was hard for him to travel every week to Aseer region to attend classes, while some others dropped because they could not study and work at the same time. In our study, a significant number of participants are the employees in both government, and private sectors and still a very considerable number are expecting to pursue their graduate degrees if the afore-mentioned barriers are resolved. Based on that, two more questions were distributed among the participants. One of them is to get their opinions, whether is it feasible to have online classes. The study revealed that among the participants' both government and private sectors employees shown the importance to have online classes with (69.56\%). The overall score is considerable using the Chisquare test with p-value $<.05$, as presented in Table VII. Besides, the second question was to get the participants opinions and responses on the importance of a comfortable schedule and time of classes of graduate programs. The study revealed that among the participants' both government and private sectors employees shown the importance to have a comfortable schedule and time of classes with (95.65\%). The overall score is considerable using the Pearson Chisquare test with p-value $<.05$, as presented in Table VIII.

TABLE VII. RELATIONSHIP BETWEEN PARTICIPANTS' OCCUPATION (EMPLOYMENT) AND THEIR OPINION ON THE IMPORTANCE OF HAVING ONLINE CLASSES USING CHI-SQUARE TEST

\begin{tabular}{|l|l|l|l|l|}
\hline \multirow{2}{*}{ Occupation } & \multicolumn{4}{|l|}{ Participants' views and observations on the importance to have online classes } \\
\cline { 2 - 5 } & $\begin{array}{l}\text { Important } \\
\text { n (\%) }\end{array}$ & $\begin{array}{l}\text { Neutral } \\
\text { n (\%) }\end{array}$ & $\begin{array}{l}\text { Not important } \\
\text { n (\%) }\end{array}$ & \multirow{2}{*}{$\begin{array}{l}\mathrm{X}^{2}(4, N=363)=35.38, \\
P<0.00001\end{array}$} \\
\hline Employee & $176(69.56 \%)$ & $51(20.16 \%)$ & $26(10.28 \%)$ & $22(31.89 \%)$ \\
\hline Students & $23(33.33 \%)$ & $24(34.78 \%)$ & $4(11.11 \%)$ & $1(20 \%)$ \\
\hline Unemployed & $22(61.11 \%)$ & $10(27.78 \%)$ & $2(40 \%)$ & $P$ \\
\hline
\end{tabular}

TABLE VIII. RELATIONSHIP BETWEEN PARTICIPANTS' OCCUPATION (EMPLOYMENT) AND THEIR OPINION ON THE IMPORTANCE OF COMFORTABLE SCHEDULE AND TIME OF CLASSES USING CHI-SQUARE TEST

\begin{tabular}{|l|l|l|l|l|}
\hline \multirow{2}{*}{ Occupation } & \multicolumn{4}{|l|}{ Participants' views and observations on the importance of a comfortable schedule and time of classes } \\
\cline { 2 - 5 } & $\begin{array}{l}\text { Important } \\
\text { n (\%) }\end{array}$ & $\begin{array}{l}\text { Neutral } \\
\text { n (\%) }\end{array}$ & $\begin{array}{l}\text { Not important } \\
\mathbf{n}(\%)\end{array}$ & \multirow{2}{*}{$\begin{array}{l}\text { P value } \\
X^{2}(4, N=363)=22.99, \\
P=0.000801\end{array}$} \\
\hline Employee & $242(95.65 \%)$ & $6(2.37 \%)$ & $5(1.98 \%)$ & $2(2.90 \%)$ \\
\hline Students & $60(86.96 \%)$ & $7(10.14 \%)$ & $2(5.55 \%)$ & $1(20 \%)$ \\
\hline
\end{tabular}




\section{DisCUSSION AND RECOMMENDATIONS}

The present research was conducted to analyze the scopes of starting new postgraduate computer and engineering programs at Najran University (NU), Kingdom of Saudi Arabia. In the current study, almost less than half of participants are able to academically communicate in English. Among the participants, about half of responders started a graduate program before, and only $11 \%$ was able to complete their study. According to the survey, a significant number of participants want to pursue their graduate degree. However, it is essential to ease the limitations, bridging the barriers to start a new postgraduate computer and engineering programs at Najran University.

It has been found that the native language in Najran is Arabic and mode of instruction in computer and engineering fields is in English. Hence, it is vital to include the English language as one of the graduate programs admission requirements so that students' English proficiency level can be improved. Besides, the dropped out rate is very high among the postgraduate students who get admitted to the programs before. The main reasons for dropped out were the distance the students need to travel every week to Aseer region to attend classes and uncomfortable time table for the students who were doing jobs at the same time. Hence the study revealed that among the participants' both government and private sectors employees shown the importance to have online classes and to have a comfortable schedule and time of courses based on the data presented in Table VII and Table VIII.

\section{CONCLUSION}

This study indicated the main barriers and their possible solutions to starting graduate programs at higher education institutions include Najran University (NU), Kingdom of Saudi Arabia. The factors outlined in this study can help higher education institutions and organizations to start graduate programs in finding promising solutions such as increasing English language proficiency, reducing drop rate at graduate levels. An indispensable limitation of the study was recall bias so that some participants might have other reasons for not continuing their previously enrolled graduate programs, but they could not remember it. A widespread future study is recommended, utilizing random sampling and a detailed assessment of responses of respondents.

\section{ACKNOWLEDGMENT}

The author would like to express his gratitude to the ministry of education and deanship of scientific research in Najran University, Kingdom of Saudi Arabia for their financial and technical support under code number NU/ESCI/17/077.

\section{REFERENCES}

[1] Saudi Arabia Vision 2030, “Quality of Life Program,” Government of Saudi Arabia. Accessed: Jan. 08, 2020. [Online]. Available: https://vision2030.gov.sa/sites/default/files/attachments/QoL\%20Arabic _0.pdf,.

[2] Najran Region Manucipality, “Najran Region Manucipality Website.” Accessed: Jul. 25, 2020. [Online]. Available:
http://www.najran.gov.sa/AboutNajran/Pages/NajranGeographically.asp $\mathrm{x}$.

[3] K. Eriksson, "STARTING POSTGRADUATE EDUCATION AT A SMALL UNIVERSITY,” Öneri Dergisi, vol. 4, no. 16, pp. 51-54, Jan. 2001, doi: 10.14783/maruoneri.727414.

[4] Cullen, D. J., Pearson, M., Saha, L. J., \& Spear, R. H. (1994). Establishing effective PhD supervision. Canberra: AGPS.

[5] Cobbing, S., Maddocks, S., Govender, S., Khan, S., Mbhele, M., Naidoo, K., Tootla, S. \& Weston, C., 2017, 'Physiotherapy postgraduate studies in South Africa: Facilitators and barriers', South African Journal of Physiotherapy 73(1), a335. https://doi.org/10.4102/sajp. v73i1.335.

[6] Stathopoulos, I. \& Harrison, K., 2003, 'Study at master's level by practising physiotherapists', Physiotherapy 89(3), 158-169. http://dx.doi.org/10.1016/ S0031-9406(05)61032-2.

[7] Gosling, S., 1999, 'Physiotherapy and postgraduate study: A follow-up discussion paper', Physiotherapy 85(3), 117-121. https://doi.org/10.1016/S0031-9406(05)65690-8.

[8] Sran, M.M. \& Murphy, S., 2009, 'Postgraduate physiotherapy training: Interest and perceived barriers to participation in a clinical master's degree programme', Physiotherapy Canada 61(4), 234-243. http://dx.doi.org/10.3138/physio.61.4.234.

[9] Glover, P., Bulley, C. \& Howden, S., 2008, 'Influences on physiotherapists when deciding to study at Masters level: An exploratory study', Advances in Physiotherapy 10(1), 14-20. https://doi.org/10.1080/14038190701474278.

[10] Murray, R. \& Newton, M., 2008, 'Facilitating writing for publication', Physiotherapy 94, 29-34. http://dx.doi.org/10.1016/j.physio.2007.06.004

[11] Hamzat, T.K. \& Amusat, N.T., 2002, 'Belief and participation with clinical physiotherapists in research', South African Journal of Physiotherapy 58(2), 32-34.

[12] Huang, R., \& Turner, R. (2018). International experience, universities support and graduate employability-perceptions of Chinese international students studying in UK universities. Journal of Education and Work, 31(2), 175-189. https://doi.org/10.1080/13639080.2018.1436751.

[13] Noorelahi, M. M., Soubhanneyaz, A. A., \& Kasim, K. A. (2015). Perceptions, barriers, and practices of medical research among students at Taibah College of Medicine, Madinah, Saudi Arabia. Advances in medical education and practice, 6, 479-485. https://doi.org/10.2147/AMEP.S83978.

[14] Al-Zubaidi, K., \& Rechards, C. (2010). Arab Postgraduate Students in Malaysia: Identifying and overcoming the cultural and language barriers. Arab World English Journal, 1(1), 107-129.

[15] Sajid, M. R., Laheji, A. F., Abothenain, F., Salam, Y., AlJayar, D., \& Obeidat, A. (2016). Can blended learning and the flipped classroom improve student learning and satisfaction in Saudi Arabia?. International journal of medical education, 7, 281-285. https://doi.org/10.5116/ijme.57a7.83d4.

[16] Sandhu, M., Sidique, S., \& Riaz, S. (2011). Entrepreneurship barriers and entrepreneurial inclination among Malaysian postgraduate students. International Journal of Entrepreneurial Behaviour and Research, 17(4), 428 - 449. https://doi.org/10.1108/13552551111139656

[17] Jippes, E., Luijk, S.V., Pols, J., Achterkamp, M., Brand, P., \& Engelen, J.V. (2012). Facilitators and barriers to a nationwide implementation of competency-based postgraduate medical curricula: A qualitative study. Medical Teacher, 34, e589 - e602.

[18] Symons, M. (2001). Starting a coursework postgraduate degree: The neglected transition. Retrieved July, 8, 2011.

[19] Boyle, Peg \& Boice, Bob 1998, 'Best Practices for Enculturation: Collegiality, Mentoring and Structure' in The Experience of Being in Graduate School: An exploration, Ed Anderson, Melissa, New Directions for Higher Education No 101, Jossey Bass Publishers, San Francisco:87-94.

[20] Youngman, Michael 1994, "Supervisors' and Students' Experiences of Supervision' in Postgraduate Education and Training in the Social Sciences: Processed and Products, Ed Burgess, Robert G., Jessical Kingsley Publishers, London \& Bristol, Pennsylvania:75-104. 
[21] MacKay, Graham 1996, 'Review of the Research Postgraduate Experience at UNE' in Frameworks for Postgraduate Education, Ed Zuber-Skerritt, Outrun, Southern Cross Uni Press, Lismore:126-146.

[22] Golde, Chris 1998, 'Beginning Graduate School: Explaining First-Year Doctoral Attrition' in The Experience of Being in Graduate School: An exploration, Ed Anderson, Melissa, New Directions for Higher Education No 101, Jossey Bass Publishers, San Francisco:55-64.
[23] MacKay, Graham 1996, 'Review of the Research Postgraduate Experience at UNE' in Frameworks for Postgraduate Education, Ed Zuber-Skerritt, Outrun, Southern Cross Uni Press, Lismore:126-146.

[24] Padró, F. F., Erwee, R., Harmes, M. A., Harmes, M. K., \& Danaher, P. A. (Eds.). (2018). Postgraduate education in higher education. Springer. 